\title{
Politioppgaver og påtaleoppgaver - juristens plass i norsk politi.
}

\author{
Av politiinspekt $\varnothing \mathrm{r}$ ERIK KOSBERG, Drammen
}

\section{Politireformer.}

Den $\phi$ verste ledelse av politiet i Norge er for tiden under omorganisering og utbygging. Gjennom lengre tid har saken vært utredet $^{1}$ ) og drøftet med etatens personaleorganisasjoner f $\phi \mathbf{r}$ Regjeringen $^{2}$ ) med st $\varnothing$ tte av Stortinget ${ }^{3}$ ) besluttet at Justisdepartementet fortsatt skal være tillagt den overordnede ledelse av politiet. Forslaget om et frittstående politidirektorat ledet av en åremålstilsatt rikspolitisjef er - ihvertfall forel $\phi$ big - forkastet. Med utgangspunkt i denne prinsippbeslutning blir i skrivende stund $^{4}$ ) de f $\varnothing$ rste skritt tatt til oppbygging av en ny organisasjons- og inspeksjonsavdeling i departementet.

Et sentralt trekk ved den norske politiordning er kombinasjonen av politi og påtalemyndighet. Under drøftelsene som har funnet sted er ikke fra noe hold tatt opp tanken om å oppheve denne ordning. Fordelene er i stedet understreket ${ }^{5}$ ), og ordningen blir lagt til grunn for reformarbeidet.

Når f $\phi$ rsteamanuensis Ragnar Hauge reiser tvil om hensiktsmessigheten av denne ordning, og tar til orde for å skille politiog påtalemyndighet, og ytterligere reiser spørsmål om behovet for politiembetsmenn som utelukkende tar seg av de politimessige oppgaver ${ }^{6}$ ), rører han ikke ved et aktuelt politisk spørsmål i norsk justisforvaltning. Skal det likevel reises debatt om spørsmålene $b \phi r$ imidlertid alle sider ved den eksisterende ordning være belyst slik at grunnlaget for debatten blir best mulig og i samsvar med de faktiske forhold. Synspunktene som f $\varnothing$ rsteamanuensis Hauge gjør gjeldende på utviklingen innenfor norsk politi - premissene for hans konkluderende spørsmålsstilling -

1) Se Innstilling om den sentrale politiadministrasjon avgitt 20. november 1970 av et utvalg oppnevnt ved Kronprinsregentens resolusjon av 9. september 1966 med forhenværende riksadvokat Andreas Aulie som formann (Aulie-utvalget). - Videre Innstilling avgitt i november 1974 av en intern arbeidsgruppe i Justisdepartementet med statssekretæren som formann (Arbeidsgruppen).

$\left.{ }^{2}\right)$ St.prp. nr. 108 for $1974-75$ s. 2.

3) Innst. S.nr. 331 for 1974-75 og Stortingsforhandlinger $\mathrm{nr}$. 588 for 1975 s. $4565-4585$.

4) September 1975 .

5) Aulie-utvalgets innstilling s. 51 og 65. Arbeidsgruppens innstilling s. 55. Under stortingsbehandlingen ble spørsmålet $i$ det hele tatt ikke berørt.

${ }^{6)}$ Nordisk Tidsskrift for Kriminalvidenskab 1974 s. 210 ff, spesielt s. 222 og 223 . 
gir nemlig grunn til visse korrigerende og supplerende merknader.

Et hovedpoeng i argumentasjonen synes å være at embetsmennene - politijuristene - i sitt virke legger hovedvekten på påtaleoppgavene, mens politioppgavene i $\varnothing$ kende utstrekning dekkes av polititjenestemennene med minimal innflytelse fra embetsmennenes side. Det er ikke dette som er problemet, det er ikke her det kniper. Etaten har riktignok visse ulфste ledersp $\varnothing$ rsmål som bl. a. politiembetsmennenes egen organisasjon har arbeidet med i den senere tid, men disse springer ikke ut av kombinasjonen politi og påtalemyndighet og er heller ikke spesifikke for embetsmennene. Dette skal jeg komme tilbake til i et avsluttende kapitel.

\section{Hovedtrekk ved den norske politiordning.}

Politiet og den borgerlige påtalemyndighet er som nevnt forent i samme etat, det vil si på det lokale plan - i politidistriktene. Politimesteren, som har ansvar for og leder polititjenesten i sitt distrikt, jfr. politilovens ${ }^{7}$ ) $\S 3$, er sammen med de underordnede embetsmenn, også tjenestemenn ved påtalemyndigheten, jfr. straffeprosesslovens $\S 72$. Ved etterforsking av straffbare handlinger og utøvelse av påtalefunksjoner står politiet under ledelse av riksadvokaten og distriktets statsadvokat, jfr. straffeprosesslovens $\S 75$. I forbrytelsessaker er politiembetsmennenes kompetanse begrenset til å lede etterforskingen og anvende rettergangsskritt under denne. I forseelsessaker ${ }^{8}$ ) har politimesteren også selvstendig påtalerett, jfr. straffeprosesslovens $\S 75$.

Den polititjenstlige, $\varnothing$ konomiske og personellmessige forvaltning ledes av Justis- og politidepartementet som etter politilovens $\S 2$ har overledelsen av politiet. Politiet står altså under dobbelt ledelse. I praksis skaper dette ingen vanskeligheter eller uklarheter.

Ut $\varnothing v e l s e$ av påtalemyndighet krever juridisk utdannelse. Men også ellers er politiets virke rettshåndhevende tjeneste, både prinsipielt sett og i daglig praksis. Politilovens $\S 1$ gir uttrykk for dette. Ved siden av å forf $\phi$ lge lovbrudd er politiets oppgaver definert til å opprettholde den offentlige orden og utføre andre oppgaver som etter lov eller sedvane påhviler politiet. Den alminnelige orden opprettholdes ved å håndheve lovbestemmelser som beskytter denne, og om n $\varnothing$ dvendig bruke makt innenfor rettsordenens ramme ved siden av strafferettslige sanksjoner.

7) Lov om politiet av 13. mars $1936 \mathrm{nr} .3$.

8) If $\varnothing$ lge straffelovens $\S 2$ handlinger som er omhandlet i straffelovens tredje del, i lovgivningen for $\varnothing$ vrig straffbare handlinger som kan medføre inntil 3 måneders fengselsstraff og ved høyere strafferamme kun hvis det er uttrykkelig bestemt at de er forseelser. 
Oppgaver som etter lov eller sedvane er lagt til politiet er bl. a. en rekke forvaltningsmessige gjøremål som alle har sitt legale grunnlag i gjeldende lovgivning ${ }^{9}$ ). Forvaltningslovens ${ }^{10}$ ) saksbehandlingsregler, som bygger på det kontradiktoriske prinsipp og kravet til grunngitte avgjørelser, skjerper på sin side kravet til juridisk innsikt hos den som skal lede og ha ansvar for behandlingen av disse saker.

De sentrale trekk ved politiordningen med foreningen av politiog påtalemyndighet $\mathrm{i}$ distriktene, den rettshåndhevende tjeneste og de forvaltningsmessige gjøremål, leder til at juristene får en sentral plass både i den sentrale politiadministrasjon og i den lokale politiledelse ${ }^{11}$ ).

Denne konsekvens forsterkes av den politiske utvikling som har funnet sted med $\phi$ kende offentlig kontroll og styring av viktige samfunnsområder. For en vesentlig del er dette skjedd gjennom lovgivning som i tillegg til straffetrussel har bygget opp tilsynsorganer med kontrollerende myndighet på de respektive forvaltningsområder. På den ene side er politiets etterforskingsoppgaver og bistandsplikt utvidet mens myndigheten på den annen side er avgrenset i relasjon til disse kontrollorganer ${ }^{12}$ ). Oftere enn f $\phi \mathbf{r}$ oppstår spørsmålet om politiets kompetanse og grensene for denne.

Behovet for juridiske kvalifikasjoner i politiarbeidet betyr imidlertid ikke at det kreves juridisk utdannelse for å utf $\varnothing$ re alle gjøremål som påhviler politiet. Mange og viktige gjøremål under etterforsking, i ordenstjeneste og ved behandling av forvaltningssaker kan utf $\phi$ res av tjenestemenn uten juridisk utdannelse, men med etatsmessig fagopplæring. Poenget er at

9) F. eks. utstedelse og inndragning av førerkort, kjøreseddel for sjåfører i offentlig personbefordring, av pass og oppholdstillatelse for utenlandske statsborgere, våpentillatelse, lotteritillatelse, handelsbrev m. v.

10) Lov om behandlingsmåten i forvaltningssaker av 10. februar 1967.

11) Under stortingsdebatten om utbygging og omorganisering av den sentrale politiledelse uttalte justisministeren (St. forh. $\mathrm{nr}$. 588 for 1975 s. 4578) : „Når en utformer den sentrale politiledelse er det viktig å sikre at den makter å opprettholde den nære kontakt mellom politiet og andre deler av justisforvaltningen som kan gi en permanent påminnelse om at politiet bare er et ledd i og en del av vårt rettsapparat".

12) Som eksempler på dette kan nevnes: Lov om oppehalding av pris- og rasjoneringsf $\phi$ resegner av 9 . juli $1948 \mathrm{nr} .3$ med bestemmelser om Statens pristilsyn $\S \S 4$ og 6 og politiets plikt til bistand $\S 8$, Lov om barnevern av 17. juli 1953 nr. 4 \& 70, Bygningsloven av 18. juni $1965 \S \S 113$ og 114, Lov om kontroll med markedsf $\varnothing$ ring av 16 . juni $1972 \S \S 12-14$ om markedsrådet og forbrukerombudsmannens myndighet til å nedlegge forbud mot handlinger som er i strid med loven, sammenholdt med straffebestemmelsen i $\$ 17$. 
arbeidet utf $\phi$ res under juridisk kontroll og ledelse, og at denne ledelse bærer ansvaret for lovligheten av beslutninger og ordre som gis $\left.{ }^{13}\right)$.

Dette er ikke noe særeget for politiet. Samme prinsipp for ansvars- $o g$ arbeidsfordeling finner man $i$ den offentlige forvaltning for $\not v r i g$, f. eks. i vegvesenet, jernbanen, televerket og på sykehus. Også ved domstolene finner man dette, f. eks. i skifteog tinglysningsvesenet.

I kraft av dette prinsipp blir det en naturlig arbeidsfordeling mellom embetsmenn med juridisk utdannelse og tjenestemenn som ikke har slik utdannelse. Under etterforsking blir embetsmannens viktigste oppgave og særlige ansvar å lede denne ut fra gjeldende straffeprosessuelle bestemmelser og $\mathrm{i}$ relasjon til straffebudet som antas overtrådt. I ordenstjenesten innebærer embetsmannens lederfunksjon administrative oppgaver som f $\varnothing \mathrm{l}-$ ger av operativ tjeneste, og instruksjon og kontroll med at tjenesten utf $\phi r e s$ innenfor rammen av lovgivningens fullmakter. Tjenestemennenes oppgaver blir politiarbeid i marken og den umiddelbare ledelse av dette.

Grensen mellom ledelse og utførende ledd går derfor ikke mellom embetsmenn og tjenestemenn, men et stykke nede i tjenestemennenes rekker. Polititjenestemenn av høyeste grad som er knyttet til operativ tjeneste utf $\phi$ rer som regel til daglig administrative lederoppgaver. Operativt politiarbeid i marken blir i langt de fleste tilfelle utf $\phi \mathbf{r t}$ og ledet av politikonstabler, overkonstabler og politibetjenter, det vil si av tjenestemenn i de laveste grader. Det f $\varnothing$ lger av administrative prinsipper at avstanden fra politikammerets ledelse til utf $\phi$ rende ledd blir st $\phi$ rre jo st $\phi \mathrm{rre}$ politikammeret er, antall administrerende mellomledd $\phi$ ker. Mens politimesteren i et lite distrikt relativt ofte må engasjere seg direkte i den operative tjeneste vil politimesteren for de største korps i f $\varnothing$ rste rekke være administrerende direkt $\phi$ r.

Etterhvert som den enkelte aktuelle innsats $\varnothing$ ker i omfang og vanskelighet blir tjenestemenn av hфyere grad trukket inn i den direkte operative ledelse. Under slike oppdrag vil også politiembetsmannen finne sin naturlige plass $\mathrm{i}$ denne ledelse og $\mathrm{i}$ kraft av sin grad være $\varnothing$ verste leder under politimesteren hvis denne ikke selv deltar. Det kan være på åstedet for en alvorlig forbrytelse, ved pågripelse av farlig person, under demonstrasjoner som kan fryktes å utvikle seg til uroligheter slik at det kommer på tale å bruke makt for å gjenopprette ro og orden.

13) Jfr. $\S 9$ i Alminnelig instruks for rikets polititjenestemenn (Politiinstruksen) fastsatt første gang ved kongelig resolusjon av 6 . februar 1920: „Enhver politimann utfører på eget ansvar det som er pålagt ham. Dog er den overordnede ansvarlig for at den av ham gitte forholdsordre er lovlig“. 
I den organiserte redningstjeneste er f. eks. politimesteren og underordnede embetsmenn gilt lederfunksjoner, både i de lokale redningssentraler ${ }^{14}$ ) og på skadested.

Politiembetsmennenes direkte engasjement i den operative polititjeneste er imidlertid ikke bare begrenset til oppdrag som krever st $\varnothing$ rre politiinnsats. Ved politikamrene er etablert vaktog jourtjeneste som pålegger jourhavende embetsmann å være til stede hele døgnet slik at han kan nås over telefon eller på annen måte. Jourhavendes oppgave er på politimesterens vegne - hvis denne ikke selv utf $\varnothing$ rer jourtjenesten - å treffe avgj $\phi$ relser om rettergangsskritt under etterforsking, beslutninger av polititjenstlig og administrativ art, og dessuten lede politiinnsats i marken hvis situasjonen i den konkrete situasjon krever $\operatorname{det}^{15}$ ).

Systemet under den nåværende politiorganisasjon vever polititjenesten - etterforsking i marken og ordenstjeneste - og gjøremålene som påtalemyndighet sammen til en organisk enhet som preger tjenesteordningene ved politikamrene. Utgangspunktet blir derfor skjevt og spørsmålsstillingen uriktig når førsteamanuensis Ragnar Hauge taler om politijuristenes dobbeltrolle, som konfronterer dem med to hovedoppgaver - den ordensmessige oppgave i egenskap av politimyndighet og de strafferettslige oppgaver som påtalemyndighet.

\section{Fra kommunal til statlig politiforvaltning.}

Staten overtok politiforvaltningen fra 1. januar 1937. Førsteamanuensis Hauge hevder at på mange måter ble det viktigste resultat av dette større selvstyre for det lokale politi. Den sentrale politiadministrasjon har ikke muligheter - og til dels heller ingen myndighet - til å påvirke politiarbeidet $i$ distriktene. Politimestrene - og de $\phi$ vrige embetsmenn — blir selv overlatt å definere de oppgaver som de $\emptyset$ nsker å prioritere.

Et nærmere studium av politiordningen f $\phi \mathbf{r}$ og etter 1937 bekrefter ikke denne hypotese.

$\mathrm{F} \phi \mathrm{r}$ statsovertakelsen var den $\varnothing$ konomiske forvaltning av politiet delt mellom stat og kommune - hovedsaklig by- og ladestedskommunene hvor politikammeret hadde sitt sete. I landkom-

14) Se kongelig resolusjon av 21. september 1973 med organisasjonsplan for redningstjenesten i Norge.

15) Jourtjenesten har nylig vært gjenstand for forhandlinger mellom Justisdepartementet og Politiembetsmennenes Landsforening. I brev av 10. mai 1973 til Landsforeningen uttalte bl. a. departementet: „Fra gammelt har det vært ansett som politiembetsmennenes plikt å arbeide til de tider hyor hensynet til embetets og tjenestens tarv gjør det n $\varnothing \mathrm{d}-$ vendig. Det gjelder blant annet ledelse av politiinnsats utenfor daglig kontortid og det gjelder beredskapsvakthold i den utstrekning forholdene ved tjenestestedet gjør det nødvendig". 
munene utførte som nå lensmannen polititjeneste $\left.{ }^{16}\right)$. Overfor lensmannsetaten hadde kommunen ingen $\phi$ konomiske forpliktelser.

Kommunene dekket utgiftene til polititjenestemennenes $1 \phi n n$, materiell, utstyr og kontorlokaler, mens staten dekket utgiftene til politiembetsmennenes $l \varnothing \mathrm{nn}$, i landdistriktene også til deres kontorlokaler og skriveutstyr ${ }^{17}$ ).

Den tjenestlige forvaltning av politiet var derimot i sin helhet lagt til statsmyndighetene som hadde full kommando- og instruksjonsmyndighet over den samlede politietat, også de kommunelønte polititjenestemenn $\left.{ }^{18}\right)$. Kommunen hadde ingen direkte innflytelse på selve polititjenesten. Politiloven av 1927 åpnet adgang for kommunen til å opprette et fast utvalg til å våke over kommunens interesser vedkommende politiet. Utvalget kunne gjøre henstilling til politimesteren om forandringer i tjenesten og iverksettelse av politiforanstaltninger, men ikke gi bindende pålegg til politimesteren ${ }^{19}$ ).

Distriktsinndelingen var i hovedtrekkene den samme som nå20), og politidistriktene omfattet både by- og landkommuner. Tjenestemennene var ansatt for tjeneste $\mathrm{i}$ politidistriktet ${ }^{21}$ ). Siden lensmennene som hovedregel dekket polititjenesten i landkommunene ble tjenesten for de kommunelønte polititjenestemenn hovedsaklig utf $\phi$ rt i den kommune hvor de ble l $\phi$ nnet og hvor politikammeret hadde sete. Situasjonen er den samme i dag. Selv om tjenestemennene har politimyndighet $\mathrm{i}$ hele distriktet gjør de som regel tjeneste bare i vedkommende bykommune og ellers i landkommuner hvor politikammeret har overtatt polititjenesten.

Som før statsovertakelsen i 1937 har den sentrale politiledelse

16) Se lov om politiet av 10 . juni $1927 \S 20$ som ble avløst av $\S 5$ i politiloven av 1936 .

17) Se politiloven av $1927 \S \S 12$ og 14.

18) Se loven av $1927 \S 22$ som ga Kongen myndighet til å utferdige en alminnelig instruks for riket om polititjenesten, og politimesteren til å gi utfyllende tjenesteregler som de stedlige forhold gjorde påkrevd. - Se også Innstilling fra Politikomitéen av 1934 (Bilag til St.prp.nr. 72 for 1935) s. 7.

19) Se lovens § 17. Tanken om lokale politiutvalg er tatt opp igjen i Arbeidsgruppens innstilling s. 114, og nevnt i St.prp.nr. 108 for 197475 s. 2 - En reminisens fra den kommunale politiforvaltning finner man for $\emptyset$ vrig $i$ det forhold at kommunestyret fortsatt velger representant til politiets ansettelsesråd. Se loven av $1927 \S 3$ annet ledd og kongelig resolusjon av 18 . desember 1936.

20) 59 politidistrikter mot 54 etter 1937. Siden 1962 er landet inndelt i 53 politidistrikter.

21) Se loven av $1927 \S 5$. Allerede politiinstruksen av 1920 hadde i $\S 17$ en tilsvarende bestemmelse, som for $\phi$ vrig står uendret $\mathrm{i}$ gjeldende politiinstruks. 
i Justisdepartementet i kraft av politilovens $\S 2$ uinnskrenket kommando- og instruksjonsmyndighet over politiet. Men departementet har i praksis vist tilbakeholdenhet med å gripe inn i det operative politiarbeid. Stort sett har departementets overledelse vært begrenset til administrativ ledelse og til å gi generelle instrukser om politiarbeidet. Avgjørelser om løsning av konkrete politioppdrag har som regel bare vært truffet etter at saken er bragt inn for departementet, enten som klagesak eller av vedkommende politimester ${ }^{22}$.

Det primære ansvar og ledelsen av polititjenesten i distriktene er ved politilovens $\S 3$ og politiinstruksens $\S \S 6$ og 7 lagt til politimesteren. Dette er et kardinalpunkt i prinsippet om den desentraliserte politiledelse. De politiske og sentrale statsmyndigheter bør ikke ha for sterk og direkte innflytelse på den daglige polititjeneste og løsningen av konkrete politioppdrag. Langt på veg $\mathrm{b} \phi \mathrm{r}$ politiet ha samme uavhengighet som påtalemyndigheten. På den annen side skal ikke den lokale politiledelse bli for sterk og uavhengig av statsmakten. Som samfunnets legale maktorgan overfor borgerne må politiet være under politisk og parlamentarisk kontroll ${ }^{23}$ ).

Både $f \varnothing r$ og etter 1937 har den lokale politiledelse hatt en selvstendig stilling når det gjelder ut $\varnothing v e l s e$ av polititjeneste. På dette punkt f $\varnothing$ rte ikke statsovertakelsen til noen endring. Utviklingen $i$ de snart 40 år siden staten overtok politiforvaltningen har heller ikke f $\phi$ rt til utvidet selvstyre for den lokale politiledelse.

$\emptyset$ kende antall lovovertredelser — særlig de siste 20 år — uten korresponderende ekspansjon av politiets ressurser stiller etaten overfor det faktum at den i noen grad må velge hvilke politi- og påtaleoppgaver som skal dekkes. Kapasitetsunderskuddet gjelder også polititjenestemenn og kontorfunksjonærer, altså etaten i

22) Et eksempel på dette hadde man under „Mardøla-aksjonen“ i 1970. En flokk demonstranter sperret en anleggsvei for å hindre utbygging av Mard $\varnothing$ la-vassdraget. Politimesteren s $\phi$ kite kontakt med departementet for å rådføre seg om makt skulle anvendes for å fjerne demonstrantene eller om politiet skulle begrense seg til å gjøre bruk av lovens straffetrussel, jfr. str. $\S 329$ første ledd. Demonstrasjonen hadde et politisk siktemål, og det ble i noen grad et politisk vurderingsspørsmål om og hvor langt politimakt skulle brukes. Demonstrantene ble til slutt flyttet med makt ved hjelp av Utrykningspolitiet, jfr. note 23 , etter at de var gjort kjent med hvilken straffebestemmelse som var overtrådt og f $\varnothing$ lgene av dette.

23) Et interessant eksempel på dette omtaler Trygve Lie i sin memoarbok: Oslo - Moskva - London. Utgitt Oslo 1968, s. 58. Som justisminister kunne han ikke godta at politimestrene skulle ha adgang til å rekvirere bistand fra Utrykningspolitiet. Anmodningen måtte komme til Justisdepartementet, som skulle vurdere om det ville gi utrykningssjefen ordre til å yte bistand. Dette er fremdeles politilovens ordning, jfr. $\S \S 7$ og 9 . 
sin helhet og ikke bare embetsmennene. Prioriteringssp $\phi$ rsmål oppstår derfor ikke bare for embetsmennenes innsats, men like meget for tjenestemennene og kontorfunksjonærene.

I den utstrekning disse prioriteringssp $\phi$ rsmål ikke blir løst av overordnet ledelse må politimestrene og deres nærmeste medarbeidere ta standpunkt til disse. Det skjer f $\phi$ rst og fremst etter kategorien av lovovertredelsen og hvilket samfunnsproblem de for $\phi$ yeblikket representerer, ikke etter kriterier som politioppgaver og påtaleoppgaver. Under et system hvor politi- og påtalemyndighet er forent i samme etat kan ikke disse oppgaver skilles - det er to sider ved samme sak.

Utviklingen har f $\varnothing$ rt til at politiets innsats i st $\phi r r e$ grad enn f $\phi \mathbf{r}$ brukes til behandling — etterforsking og forberedelse til irettef $\phi$ ring - av stedfunne lovovertredelser til fortrengsel for patrulje- og spaningstjeneste og annen tjeneste, f. eks. trafikkovervåking, i forebyggende $\phi y e m e d$. Det betyr at politiet ikke styrer prioriteringssp $\phi$ rsmålene helt ut, men at disse til en viss grad blir styrt av begivenhetene som finner sted ${ }^{24}$ ).

\section{Aktuelle lederspфrsmål.}

Politiordningen - f $\varnothing \mathbf{r}$ og etter statsovertakelsen i 1937 - representerer en velavveid og for norske forhold hensiktsmessig politiorganisasjon. Samfunnsutviklingen med $\phi$ kte krav til politiet har imidlertid avdekket visse svakheter ved etatens ledelse. Det gjelder både den sentrale ledelse og ledelsen på det lokale plan.

Den overordnede politiledelse - Justisdepartementet - har som tidligere nevnt stort sett begrenset seg til administrativ, $\phi k$ konomisk og forvaltningsmessig ledelse av etaten. Den arbeidsmessige kapasitet har neppe strukket lenger. Etaten har savnet en faglig ledelse som tar seg av det langsiktige planleggings- og organisasjonsarbeid, sentral koordinering og prioritering av politiets oppgaver ledsaget av inspeksjons- og instruksjonsvirksomhet $\mathrm{i}$ den ytre politietat. I de siste par år er markert som politisk mål for justisforvaltningen at politiet skal tilf $\phi$ res større ressurser slik at etaten bringes i takt med samfunnsutviklingen og settes i stand til å møte tidens krav. Opprusting av politiet aksentuerer imidlentid behovet for sterkere overordnet ledelse av etaten. På den annen side må ikke dette bryte prinsippet om den desentraliserte politiledelse med operativ selvstendighet i det konkrete tilfelle.

Men også det lokale plan har lederspørsmål som krever oppmerksomhet. Det dreier seg om rekruttering av politiledere,

24) Bl. a. dette spørsmål er drøftet av politifullmektig Stein Ulrich: „Påtalemyndigheten i fokus“, Lov og Rett 1974 s. 315 ff. 
etatsmessig opplæring og trening av disse. Spфrsmålet er like aktuelt for tjenestemenn som ventes å avansere til toppstillinger (stasjons- og avdelingssjef og overbetjent) som for embetsmennene.

Politiloven av 1937 stiller krav om at politimesteren skal ha juridisk embetseksamen, mens de $\phi$ vrige embetsmenn i alminnelighet $b \phi r$ ha slik eksamen (lovens $\S 3$ sjette ledd). Kongen har fått myndighet til å gi forskrifter om forutgående politiutdannelse og praksis som underordnet polititjenestemann som vilkår for utnevnelse i politiembeter ( $\S 3$ siste ledd). Slike forskrifter er ikke gitt. I midten av 1960-årene ble gjort et par fors $\varnothing \mathrm{k}$ med aspirantordning for politifullmektiger, men ordningen falt bort og er ikke senere tatt opp igjen. Ansettelse som politifullmektig - som normalt er begynnerstillingen for politiets embetsmenn skjer derfor på grunnlag av åpen konkurranse hvor hovedvekten legges på teoretiske kvalifikasjoner.

Statens politiskole - som er landets eneste undervisningsinstitusjon for politifolk — gjennomf $\phi$ rte i 1950-årene spesielle kurs for embetsmennene. Utover dette og enkelte spesialkurs, f. eks. i etterforsking av $\phi$ konomiske saker og trafikkurs, hvor både embets- og tjenestemenn deltar, finnes ingen fast etablert etatsopplæring for politiets embetsmenn.

Med hjemmel i politilovens $\S 17$ og ved kongelig resolusjon av 29. juni 1956 ble gitt forskrifter om forutgående utdannelse som vilkår for ansettelse i politiet med adgang for departementet til å gi regler om aspirantordning for polititjenestemenn. Aspirantordningen dekker bare grunnopplæringen hvor den teoretiske del skjer ved Politiskolen. Siden begynnelsen av 1960-årene har Politiskolen holdt såkalte avansementskurs, men disse gir hovedsaklig repetisjon av grunnopplæringen.

Siden h $\phi$ sten 1972 har det ved Sivilforsvarets Sentralskole ${ }^{35}$ ) vært gjennomf $\phi$ rt kurs for embets- og tjenestemenn i ledelse av redningsinnsats på skadested, og fra et noe senere tidspunkt også for ledere og stabspersonell $i$ lokal redningssentral ${ }^{26}$ ). Redningstjenesten utgj $\phi \mathrm{r}$ bare én side ved politiets virke, men prinsippene for ledelse av redningsarbeid kan i noen grad anvendes ved andre politioperasjoner av større omfang. Kursene har derfor betydning utenfor redningstjenesten. - Nevnes kan også at Politiembetsmennenes Landsforening og Norges Juristforbund i samarbeid med Justisdepartementet har arrangert kurs i 1974 og 1975 for yngre politiembetsmenn med sikte på å dyktiggjøre dem

25) Politiskolen har ikke hatt kapasitet til disse kurs.

26) Som nevnt i note 14 er ved kongelig resolusjon av 21. september 1973 fastsatt organisasjonsplan for redningstjenesten i Norge. I hvert politidistrikt er det lokal redningssentral som ledes av politimesteren med bistand av en redningsstab. 
for lederoppgaver som ,tjenestemenn ved påtalemyndigheten“ og i polititjeneste.

Politietaten mangler en fast etablert opplæringsordning med sikte på å kvalifisere embets- og tjenestemenn som politiledere ${ }^{27}$ ). En virkning av dette blir at politijuristene foretrekker tjeneste ved etterforskingsavdelinger hvor de kan gjøre bruk av kunnskaper som blir ervervet under det juridiske studium. Det vil si etterforsking av straffbare handlinger som er omhandlet i forbrytelsesdelen i den borgerlige straffelov. Forseelsene, særlig de som f $\phi$ lger av spesiallovgivningen, f. eks. alkoholloven, tolloven, skatteinnbetalingsloven, handelsloven, laksefiskeloven, lukningsvedtekter $m$. v., med unntak for trafikklovgivningen, m $\varnothing$ ter mange embetsmenn som ukjent og fremmed lovstoff. Sakene f $\phi$ les ikke tiltrekkende selv om de fra en juridisk synsvinkel kan være vel så interessante som tradisjonelle forbrytelsessaker (vinningsforbrytelser, legemskrenkelser og sedelighetsforbrytelser). Det er ikke påtaleoppgavene, men forbrytelsessakene (kriminalsakene) som er interesseområdet for en del embetsmenn. Ved politikamre med særskilt organiserte kriminalavdelinger er forbrytelsessakene lagt til disse avdelinger, mens forseelsessakene er lagt til ordensavdelingen, som også har ansvar for den utvendige ordens- og trafikktjeneste ${ }^{28}$ ).

Avansementssystemet $\mathrm{i}$ etaten gir heller ingen sikker mulighet for rekruttering av egnede politiledere. Bortsett fra politilovens $\S 3$ fjerde ledd som bestemmer at bare personer som tidligere har vært politiembetsmenn $b \phi r$ utnevnes til sjefstillinger i politiet er ikke ved lov eller forskrift satt formelle krav for avansement til lederstillinger i politiet. Utvelgelsen er nærmest negativ i den forstand at bare den som har vist seg ubrukbar blir holdt tilbake. Innenfor denne ramme følges både for politiembeter og tjenestemannsstillinger stort sett den praksis at den eldste av de brukbare søkere forfremmes. Ansiennitetsprinsippet har sterk gjennomslagskraft $\mathrm{i}$ etaten. Slik vil det antagelig være så lenge lønnsutvikling og pensjonsgrunnlag er knyttet sammen med avansement til høyere og ledende stilling. Kravet til kvalifikasjoner krysses av hensynet til befordring.

$\left.{ }^{27}\right)$ Rekrutterings- og utdannelsessp $\not$ rsmålene for politiet er for tiden under utredning av Politiutdannelsesutvalget som ble oppnevnt ved kongelig resolusjon av 10 . september 1971 . Utvalget har i 1975 avgitt en delinnstilling om rekruttering og grunnopplæring. I f $\varnothing$ lge sitt mandat skal utvalget også behandle videreutdannelsen i politiet.

${ }^{28}$ ) Lønnsmessig spiller det ingen rolle ved hvilken avdeling embetsmannen gjør tjeneste. Frem til 1974 oppnådde tjenestemenn i ordensog trafikktjeneste gjennomgående større fortjeneste på årsbasis enn ved etterforskingsavdelinger. L $\varnothing$ nnsoppgjøret i 1974 bragte endring på dette punkt, og man er nå tilbake til forholdet slik det var for en del år siden hvor „,innetjeneste“ ble foretrukket. 
Mens det er formulert bestemte krav til utdannelse i politiet både for embetsmenn og for tjenestemenn - er de $\phi$ vrige krav som bør stilles til politiledere knapt nok definert. I praksis kommer det an på hvordan den som sitter i stillingen oppfatter sin lederrolle, deres temperament og legning, om de er villig til å markere seg som leder, ta initiativ, treffe avgjфrelser og bære ansvar. I stor utstrekning er dette personlige egenskaper som er uavhengig av skoleutdannelse.

Men lederskap er også betinget av faglig sikkerhet. For den juridiske side av politivirket er embetsmennene gjennomgående kvalifisert ved sin utdannelse. Det samme gjelder tjenestemennene med grunnopplæringen de får som politiaspirant. Men for begge grupper har etaten hittil ytet liten hjelp til perfeksjonering av $\phi$ vrige kvalifikasjoner som kreves for å være politileder. 